\title{
Index Funds: Hedgers or Speculators?
}

\author{
William T. Gavin
}

$\mathrm{T}$ he commodity futures market has changed dramatically over the past five years. The Goldman Sachs Commodity Index (GSCI) rose from 235 at the end of December 2002 to 787 on the last day of May 2008-an average annual commodity price inflation rate of 25 percent. The price of agricultural commodities rose about 15 percent, and energy prices soared almost twice as fast-at 29 percent. Futures market participants normally include commercial hedgers and speculators. Commercial hedgers are firms that produce the commodity or use it in producing goods and services. For example, wheat farmers sell wheat ahead of the harvest to hedge against a falling price at harvest time. On the other side of the market, the bread and pasta producers buy wheat in advance to hedge against the risk of rising prices in coming months (and years). Speculators bring liquidity to the market and are generally believed to make the market more efficient in discovering the equilibrium price.

One big change in this market is the growth of index funds that invest in long positions. In 2002, only a small percentage of the long positions were held by such funds. Over the past five years, however, the index funds' long positions have grown. They now represent a significant share of the investment in commodity futures. The rise of index funds has been accompanied by a rapid rise in the use of derivatives based on commodity price indices. Note, however, that not all of these investors are speculators.

Although it is true that they are not hedging risk in the commodity markets, many large investors, including the employee pension funds for the federal government and the state of California, are using the commodity futures index funds to hedge risk in the stock and bond markets.

Why the rapid growth in the use of commodity futures to hedge risk in the stock and bond markets? Readers seeking to understand this change are referred to a recent research paper by Gary Gorton and Geert Rouwenhorst in which they develop a data set on commodity futures prices that spans the period from July 1959 to December 2003. ${ }^{1}$ They analyze the return an investor would have earned on a long position in an equally weighted portfolio of investments in a broad set of commodity futures. They show that such an investment displays the risk-return characteristics of a similar investment in equities. The most interesting fact they uncover, however, is that the return to commodity futures was negatively correlated with returns in both stocks and bonds. The commodity future returns are positively correlated with inflation, unexpected inflation, and changes in expected inflation. In other words, an investment in commodity futures would have been an effective hedge against the business cycle and inflation risk that had been thought difficult, if not impossible, to hedge. Of course, the history of returns likely would be different if large investors actually had been using commodity markets in this way during the past 47 years.

The recent increase in commodity futures prices has been accompanied by a large increase in volatility that has raised the cost of maintaining margin accounts. Anecdotal evidence from the Eighth Federal Reserve District suggests that the rising costs of maintaining margin accounts have led to less commercial hedging in the cotton and grain markets-at least by the smaller market participants. This development is interesting because the commodity futures market now is being asked to hedge not just the risks to producers and consumers of commodities, but also to hedge risks in the much larger markets for stocks and bonds. This is uncharted territory. It will be interesting to see whether the commodity sector is large enough to effectively insure all this risk. -

${ }^{1}$ See Gary B. Gorton and K. Geert Rouwenhorst, "Facts and Fantasies about Commodity Futures," Financial Analysts Journal, 2006, 62(2), pp. 47-68.

\section{S\&P GSCI Nearby Index (January 2, $1970=100$ )}

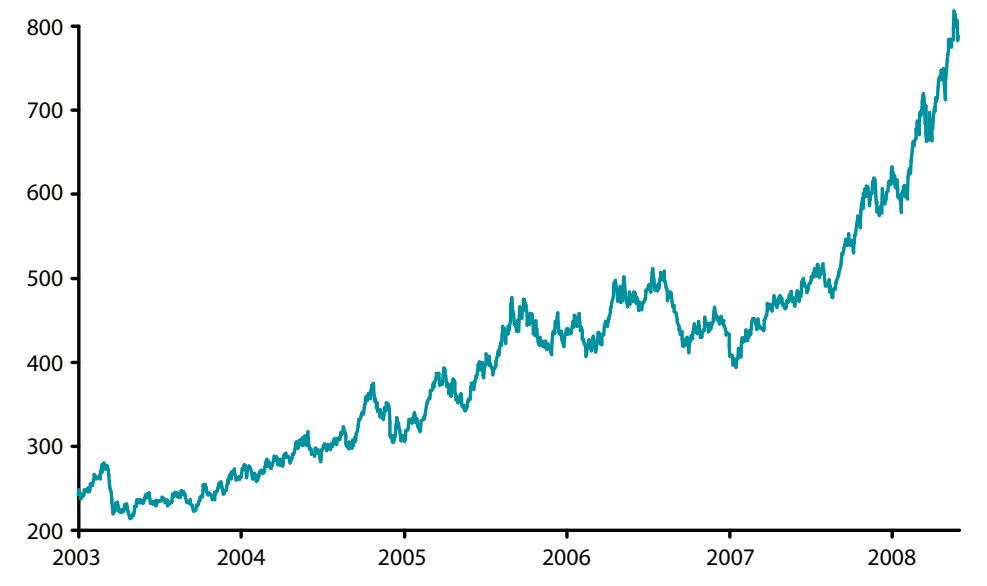

